\title{
Дакументы Юрыя Туронка ў Беларускім дзяржаўным архіве-музеі літаратуры і мастацтва
}

\section{Dokumenty Jerzego Turonka w zbiorach Białoruskiego Państwowego Archiwum Muzeum Literatury i Sztuki}

Tekst dotyczy archiwum Jerzego Turonka zdeponowanego w zbiorach Białoruskiego Państwowego Archiwum Muzeum Literatury i Sztuki w Mińsku (BDAMLiM). Na zespół Turonka składa się wiele dokumentów biograficznych, rękopisów i maszynopisów prac autora, zdjęcia i korespondencja z dziesiątkami osób z różnych krajów. Ogromną część zespołu archiwalnego stanowią dokumenty zebrane przez historyka w trakcie badań. Są to m.in. materiały ze zbiorów Mariana Pieciukiewicza, Viery Muraški i innych. Pierwsza część tego archiwum trafiła do Mińska na początku lat 90. XX wieku, pozostałe zaś zostały przekazane niedawno. Proces przekazania trwa do dziś. Dzięki J. Turonkowi do zbiorów BDAMLiM trafiło wiele rzadkich książek i czasopism.

Słowa kluczowe: Jerzy Turonek, zespół archiwalny, dokumenty, korespondencja, kolekcja

Кантактуючы з беларускімі дзеячамі розных краін, Юры Туронак часта разам 3 лістамі атрымліваў ад сваіх адрасатаў і часткі іх архіваў або кнігазбораў. Гэта прывяло гісторыка да думкі пра неабходнасць упарадкавання атрыманых рарытэтаў, а таксама і ўласных дакументаў, і перадачы іх на сталае захоўванне ў нейкае сховішча. 
3 пачатку 1990-х гадоў Ю. Туронак наладзіў кантакт 3 тады яшчэ Цэнтральным дзяржаўным архівам-музеем літаратуры і мастацтва БССР у Мінску, куды паступова стаў перадаваць розныя дакументы і выданні. Ужо 20 красавіка 1990 года Ю. Туронак напісаў заяву аб перадачы ў архіў-музей рукапісаў сваёй кнігі «Беларусь пад нямецкай акупацыяй», нарысаў, дакладаў, а таксама некаторых кніг і перыядычных выданняў. I надалей на працягу некалькіх гадоў з Варшавы ў Мінск ён накіроўваў дакументы, друкаваныя выданні і іншыя прадметы. Нешта прывозіў асабіста, наведваючы навуковыя мерапрыемствы ў Мінску, рэшту перадаваў праз знаёмых. Працэс перадачы каштоўнасцей з прыватных збораў гісторыка ў архіў-музей адлюстраваўся ў перапісцы з дырэктарам Ганнай Сурмач. У лістах і паштоўках гісторык дакладна пазначаў, што перадае ў архіў.

Ніжэй публікуюцца некаторыя пісьмы Ю. Туронка да Г. Сурмач (з захаваннем лексічных і сінтаксічных асаблівасцей арыгінальных дакументаў).

\section{Дакумент № 1}

Варшава, 3.10.1990 г.

Добры дзень, спадарыня Ганна!

На жаль, не змог пазваніць Вам перад ад’ездам з Менска. Недзе прапала картачка з Вашым тэлефонам, знайшлася толькі тут, у Варшаве. Прабачце. Іншай страты не было: кніжку Сачанкі атрымаў літаральна ў апошнюю гадзіну, так што з гэтым праблемы няма.

Толькі пад канец верасня атрымаў Ваш ліст ад 2 жніўня, разам 3 некалькімі ліпеньскімі «Нёманамі». За ўсё дзякую.

Прыемна было з Вамі пазнаёміцца асабіста. Шкадую толькі, што так мала часу было на размовы. Гэтаму не спрыяў «арганізацыйны канвеер» па дарозе ў Полацк і назад. Спадзяюся на наступны раз. А калі будзеце ў Варшаве, не мінайце нашай хаты. [...]

На днях, здаецца, будзе нагода паслаць у Ваш архіў крыху старыны. Падрыхтаваў два невялікія пакеты - можа добрыя людзі захочуць узяць. Змест падаю на аддзельных картачках. Буду ўдзячны за некалькі слоў аб атрыманым (як заўсёды). 
Увогуле, гэтага дабра можа быць крыху болей. Буду пасылаць часткамі пры нагодзе. Вядома, аб вартасці матэрыялу будзеце рашаць пасля азнаямлення.

Жадаю Вам усяго найлепшага!

3 прывітаннем, Юры Туронак.

Дакумент № 2

Белавежа, 6.10.1990 г.

Дзякую за перадачу, якую тут атрымаў ад С. Шупы, асабліва за здымак з Полацка.

Юр.

1 пакет

В. Ярмалковіч. Крывы горад. Вільня.

Літ.-маст. зборнік. 1970. № 1 і 2.

Ю. Жывіца (сапр. прозв. Юры Попка):

- Пушча шуміць, 1963;

- Праз слёзы, 1951;

- Носьбіт ідэі, 1964.

«Беларус» 8/90 - «Кантакт» №4.

2 пакет

«Баявая ўскалось» - 11 сшыткаў.

Кавыль. Пад зорамі белымі. 1954.

Ruža.

Szkice. № 8/1988.

Program rozwoju kultury w woj. białostockim (ні слова пра нашу).

Wystawa sztuki ludowej.

Setna rocznica Kupały i Kołasa.

Byelorussian Folk Festival. 1977.

\section{Дакумент № 3}

\section{Шаноўная Ганна!}

Варшава, 19.12.1990 г.

Карыстаючыся нагодай шлю:

1. Міркулевіча (старога мінчаніна) „Refleksje białoruskie” (машынапіс);

2. Ярмалковіча - пра БХД і БСС;

3. «Весткі беларусаведы» - тры (там жа працы Ярмалковіча). 
Адначасова прыміце мае найлепшыя калядныя і навагоднія віншаванні.

Прабачце, пішу амаль на калене.

3 прывітаннем, Ю. Туронак.

Дакумент № 4 (паштоўка)

Добры дзень, спадарыня Ганна!

Варшава, 4.02.1991 г.

16-17 лютага спадзяюся выступіць на Браслаўскіх чытаннях з дакладам пра друйскі марыянскі манастыр. Калі Вас не сустрэну, перадам камусь часопісы і іншае для Вашага архіва.

3 прывітаннем, Юр. Туронак.

\section{Дакумент № 5}

\section{Шаноўная спадарыня Ганна!}

Варшава, 14 лютага 1991 г.

Карыстаючыся нагодай, шлю Вам чарговыя матэрыялы.

1. Раней выслаў Вам некалькі тэкстаў Віктара Ярмалковіча, а сёння шлю ягоную біяграфію, якую прапаную далучыць да камплекта. Прынамсі, будзе менш-больш вядома, які быў лёс гэтага чалавека.

2. Маю архіўную папку «Матэрыялы дзядзькі Антона». Артыкул быў апублікаваны, магчыма, ён у Вас ёсць, а калі не, то будзе. Увогуле, хацеў бы, каб у Вашым архіве былі ўсе мае найважнейшыя апублікаваныя працы. Спадзяюся іх прывезці ў Мінск 24 мая г. г. (у сувязі з устаноўчым сходам Міжнароднай асацыяцыі беларусістаў).

3. «Летапіс беларускай эміграцыі», № 73 i 74. I на мой ліст Панькоў не адказаў. Пачакаем цярпліва - можа чалавек хворы, яму ўжо бадай каля 84-85 гадоў. Гэтую справу абмяркуем пры сустрэчы. Калісь перадаваў некалькі экзэмпляраў «Летапісу» Валі Трыгубовіч і адзін-два яшчэ камусь, але не памятаю каму (Шупу ці Янушкевічу Язэпу?). Можа, яны былі б згодны іх перадаць у Ваш архіў?

4. Мой даклад пра друйскі манастыр «ва ўсім творчым працэсе», г. зн. чарнавікі, скарочаная версія для бюлетэня «Браслаўскіх чытанняў» і (пакуль што) апошняя версія + тры здымкі. Усё непатрэбнае выкідайце.

16 лістапада 1990 г. звяртаўся да Вас з запытаннем, ці патрэбныя Вам пераклады Пятроўскага і Веры Рыч. Напішыце пры нагодзе.

Як заўсёды, буду ўдзячны за вестку аб атрыманні пасылкі, як заўсёды, шлю найлепшыя пажаданні і прывітанні. 
5. «Конадні» № 1-7 (камплект) [дапісана ад рукі. - Н. Г.]. Ю.Туронак

Дакумент № 6

\section{Шаноўная спадарыня Ганна!}

Варшава, 28.02.1991 г.

Спадзяюся, што Вы ўжо атрымалі матэрыялы, якія згадзілася перадаць сп-ня Таццяна Святловіч. Сёння, дзякуючы новай нагодзе, шлю ў Ваш архіў наступныя выданні, якія з'явіліся ў першыя пасляваенныя гады на чужыне:

Сяднёў.

На край святла. 1947.

Спадзяванні. 1947.

У акіяне ночы. 1947.

Ля ціхай брамы. 1955.

Салавей.

Звіняць званы святой Сафіi. 1946.

Сіла гневу. 1946.

Крушына.

Лебедзь чорная. 1947.

Кавыль.

Пад зорамі белымі. 1954.

Цяжкія думы. 1961.

Юхнавец.

Шорах моўкнасці. 1956.

Калумбы. 1967.

Клішэвіч.

Далячынь. 1964.

Шакун.

След пяра. 1964.

Ніна Змагарка.

Памятай бацькаўшчыну! 1950.

Е. Кіпель.

Аснова маралі. 1953.

К. Вітан.

Лявон Вітан-Дубейкаўскі. 1954.

Я. Станкевіч. Маленькі маскоўска-беларускі слоўнічак. 1953. 
Национальность и происхождение Ивана Федорова. 1966 (магчыма, выдадзеная Янкам Станкевічам).

Пішыце хоць некалькі слоў, ці атрымоўваеце пасылкі.

3 прывітаннем, Ю.Туронак.

\section{Дакумент № 7}

\section{Шаноўная спадарыня Ганна!}

Варшава, 17.03.1991 г.

Дзякую за ліст ад 6 сакавіка. Добра ведаць, што часта незнаёмыя і выпадковыя людзі акуратна перадаюць Вам пасылкі. Дзякую таксама за «Старажытную Беларусь» Ермаловіча, якую вельмі хацеў мець.

У суботу, 24 сакавіка, паедзе ў Менск мой малады прыяцель Мікола Ваўранюк, аднак сёння, пішучы гэты ліст, не ведаю, што ён $з$ сабой зможа ўзяць. Маю дзве пасылкі, з якіх, спадзяюся, адна паедзе ў суботу:

1. «Летапіс», камплект, які на Вашу і маю просьбы да Панькова прыслаў яго супрацоўнік Пеляса. Ад яго таксама розныя старыя выданні, якіх пераважную частку Вы атрымалі. «Летапіс» лічу важным здабыткам. Гэта т. зв. новая серыя. Раней Леанід Галяк выпусціў у Нямеччыне і ЗША 14 нумароў, з якіх магу Вам прыслаць № 12. Іншых пакуль што няма. Калісь Панькоў абяцаў зрабіць ксераксы, аднак, відаць, не меў такой магчымасці. Дарэчы, здаецца, старая серыя мела іншы характар. Аб пачатках «Летапісаў» гл. «Паказьнік беларускіх выданьняў на чужыне», 1952, с. 36. Мы ўжо падзякавалі, лічу, што з увагі на паліткарэктнасць справы пакуль што гэтага не рабіце.

2. Ля чужых берагоў (альманах). 1955.

Брага (Тумаш). Пытанне імя Скарыны. 1967.

Палягошка. Успаміны. 1968.

Юстапчык. Каханы горад. 1948.

Жылка. Творы (частка кнігі). 1953.

Косараў. Англа-беларускі слоўнік. 1982.

Засецкі. Міністэрства беларускіх спраў. 1919.

Богогласник. 1912.

Беларускі царкоўны спеўнік. 1979.

Ёсць яшчэ і іншыя матэрыялы, якія буду пакрысе высылаць пры нагодзе або сам прывязу ў Менск, калі атрымаю запрашэнне на з'езд Міжнароднай асацыяцыі беларусістаў, праектаваны на канец мая. За копію пра Івана Фёдарава дзякую, гэтым займацца не буду.

3 прывітаннямі і найлепшымі пажаданнямі, Ю.Туронак. 


\section{Дакумент № 8}

Шаноўная спадарыня Ганна! [...]

Варшава, 17.10.1991 г.

Спадзяюся, што Валерыя перадала Вам мае матэрыялы. 3 іх найважнейшыя - часопіс «Беларуская моладзь», чарговы летапіс. У «БМ» цікавыя ўспаміны «Падрэзаныя крылы» (№ 22-23). Пры нагодзе прашу паведаміць новы адрас і тэлефон ЦДАЛіМ.

3 прывітаннем, Юры Туронак.

Відавочна, што кантакты і далей працягваліся, аднак лістоў пазнейшага часу не захавалася.

У архіве-музеі быў створаны асабісты фонд Ю. Туронка, а першы вопіс быў прыняты экспертна-метадычнай камісіяй 8 верасня 1993 года: 292 дакументы, а таксама друкаваныя выданні і музейныя прадметы. Праўда, са спадзяваннем на далейшае паступленне дакументаў навукова-тэхнічную апрацоўку фонда тады вырашылі не рабіць.

Цяперашняя кіраўніца БДАМЛіМ Ганна Запартыка таксама добра знаёма з Ю. Туронкам, сустракалася $з$ ім на розных мерапрыемствах.

У канцы 2014 года БДАМЛіМ звярнуўся да Ю. Туронка 3 прапановай працягнуць фарміраванне яго фонда. Гісторык з радасцю адгукнуўся. Ужо ў красавіку 2015 года з Варшавы была перададзена новая вялікая група дакументаў, і на працягу наступных гадоў архіў-музей атрымаў значнае папаўненне згаданага фонда. У выніку, быў складзены другі здатачны вопіс амаль на 2000 дакументаў.

Усё перададзенае Ю. Туронкам у архіў-музей было сістэматызавана паводле традыцыйнай для фондаў асабістага паходжання схеме, але перш, чым падаць больш дакладнае апісанне фонда, варта вылучыць некалькі асобных набораў дакументаў, каментарыі да якіх напісаў сам фондаўтваральнік. 


\section{Дакументы Веры Маслоўскай}

I ў перададзеных у пачатку 1990-х гадоў дакументах, i ў атрыманых на працягу апошніх гадоў важнае месца займаюць матэрыялы, звязаныя $з$ жыццём і дзейнасцю грамадскай дзяячкі і паэтэсы Веры Маслоўскай. Да першага камплекта яе дакументаў, перададзеных у БДАМЛіМ, Ю. Туронак дадаў адмысловую нататку, якую тут публікуем.

\section{Дакумент № 9}

Варшава, 27.10.1990 г.

Нататка для архіва літаратуры і мастацтва

3 паловы 60-х гадоў пачаў я вывучаць гісторыю беларускіх школ на Беласточчыне. Між інш., цікавіўся становішчам у вёсцы Агароднічкі, што каля Супраслі - якая там была школа «за саветаў» (1939-1941) і ў час нямецкай акупацы, хто вучыў і г. д. Мне рэкамендавалі пагаварыць са старой настаўніцай, Верай Карчэўскай, якая тады вучыла і зараз жыла ў Супраслі.

У ліпені 1967 г. адведаў Веру. Прыняла мяне стрымана, насцярожана, на пытанні адказвала неахвотна, спасылаючыся на не найлепшую памяць. Між інш., сказала, што за немцаў яна вучыла ў Агароднічках, але толькі да Каляд 1941 г., потым школу закрылі і вучыла тайна, што пагражала рознымі рэпрэсіямі. Гэтая яе інфармацыя была выкарыстана мною ў артыкуле «Акупацыйная школьная палітыка III рэйха ў Беластоцкай акрузе» („Przegląd historyczno-oświatowy” 1976, № 63, s. 310), які выслаў ёй з падзякай.

Праз дзесяць гадоў зноў давялося адведаць Веру. Калі зайшоў у яе кватэрку і яшчэ не паспеў прывітацца, як трэба, угледзеў на сцяне вялікую фатаграфію «Беларускія вучыцельскія курсы» (Вільня, 1919 г.). Запытаў яе неяк недарэчна: «Чаму гэтая фатаграфія ў Вас?» Тады Вера запытала: «А чаму гэта Вас цікавіць?» Тады я: «А таму, што і ў мяне ёсць такая ж, мой бацька быў там на гэтых курсах. Во яго здымак».

Вера крыху задумалася, памаўчала і раптам клікнула: «Сыночку! Даруйце мне старой, я тады Вас абманула з гэтай школай... Была яна ў Агароднічках і пазней, у 1943/44 годзе, працавала афіцыйна, і я з мужам тады працавалі. Ды вось потым адбыліся рэпрэсіі, палякі мужа выдалі саветам, яго вывезлі... Таму баялася. А не ведала, што Вы сын Браніслава, які на тых курсах нават крыху заляцаўся да мяне». 
3 гэтага часу мы ўжо гаварылі спакойна і свабодна. У выніку, 5 сакавіка 1978 г. у беластоцкай «Ніве» з'явілася мая публікацыя «Забытая ліра Веры Мурашкі». Усё ж, відаць, Вера не пераставала баяцца, прасіла абмежавацца псеўданімам, не падаваць яе прозвішча.

Хутка, аднак, пачаў «эксплуатаваць» Веру журналіст «Нівы» Мікола Гайдук. Відаць, згадзілася на «дэканспірацыю» (гл. артыкул Гайдука).

Вера баялася не толькі нямецкай акупацыі, але і сваёй эсэраўскай прошласці. Аднак колішняя слаўная Маслоўская ў 1939-1941 гг. была Карчэўская, што пакуль што яе ратавала. Несумненна, імкнулася здабыць прыхільнасць новай савецкай улады, аб чым можна меркаваць па перапрацоўцы верша «Беларускім партызанам», які цяпер прысвячаўся «вызвольнікам-чырвонаармейцам» (гл. ксераксы вершаў). Магчыма, таму «не прызнавала» эсэраўскімі дзеячамі ні Ластоўскага, ні Бадунову, якую, дарэчы, велічала і якая мела вялікі ўплыў на Веру.

Пра ўдзел Веры ў Пражскай канферэнцыі нямала пісалася ў тагачаснай польскай прэсе, а пра яе ўдзел у падполлі на Беласточыне - у зборніку «Працэс 45-ці беларусаў» (Вільня, 1923 г.).

Пасля турмы выйшла замуж за Уладзіміра Карчэўскага, які працаваў псаломшчыкам ва ўніяцкіх цэрквах над Бугам. Пасля Другой [сусветнай. $-H$. . .] вайны лічыла сябе праваслаўнай, спявала ў царкоўным хоры ў Супраслі, была ў добрых адносінах з мясцовым праваслаўным святаром. Аднак, відаць, нешта засталося з той уніi: пераглядаючы яе паперы, заўважыў не без здзіўлення, што на пытанне аб сваім веравызнанні адказала - «грэка-каталіцкае».

Вера мела толькі адно дзіця - Валянціну, якая жыла толькі некалькі гадзін.

Мясцовыя палякі ненавідзелі Веру за арганізацыю беларускай НСШ у 1939/40 школьным годзе і навучанне па-беларуску падчас нямецкай акупацыі і непасрэдна пасля вайны. Пакідалі пагрозлівыя лістоўкі, пагражалі крывавай расправай. Па гэтай прычыне Вера з сястрой Жэняй была вымушана выехаць у Сілезію.

Вера мела некалькі беларускіх кніжак, выдадзеных у 1919-1920 гг., бадай усе перадала мне.

Сшытак вершаў недзе загінуў пасля яе смерці, засталася зробленая мной ксеракопія. Некаторыя яе вершы я прапанаваў крыху паправіць, галоўным чынам, з боку мовы, але яна не вельмі з гэтым пагадзілася.

У папцы, між інш., нашая перапіска, амаль усе здымкі, якія перадала мне, лісты жонкі ўкраінскага дзеяча Махно, Галіны, дасыланыя з Па- 
рыжа ў беластоцкую турму (арыгіналы), калекцыя пражскіх паштовак на памяць ад удзельніка Пражскай канферэнцыі і іншыя матэрыялы. Там жа ксеракс сшытка вершаў.

Юры Туронак.

Так, дзякуючы рупнасці Юрыя Туронка, у БДАМЛіМ трапілі надзвычай каштоўныя дакументы, сярод якіх яшчэ раз варта адзначыць копію сшытка 3 вершамі В. Маслоўскай (54 старонкі), машынапісы і рукапісы вершаў 1944 года, а таксама машынапісныя копіі іншых вершаў, зробленыя самім гісторыкам. Таксама перададзена копія аўтабіяграфіі В. Маслоўскай (напісана па-польску недзе ў канцы 1950-х гадоў), копія выпіскі з яе працоўнай кніжкі, ліст 3 рэдакцыі газеты «Наш сьцяг» ад 12 ліпеня 1923 года да маці В. Маслоўскай $з$ просьбай даслаць яе фотаздымак і кароткі жыццяпіс, набор паштовак з выявамі Прагі, падораны на памяць В. Анісковічам у 1921 годзе. Асаблівую цікавасць выклікаюць шэсць арыгінальных пісьмаў-паштовак за 1925-1928 гады з Парыжа ад жонкі Нестара Махно Галіны да В. Маслоўскай у беластоцкую турму. Да лістоў дадаюцца фотаздымкі Галіны і яе дачкі.

Большую частку дакументаў з архіва В. Маслоўскай, перададзеных Ю. Туронкам, складаюць арыгінальныя фотаздымкі. Гэта індывідуальныя здымкі і самой Веры рознага ўзросту, і іншых дзеячаў міжваеннай Заходняй Беларусі: Янкі Станкевіча, Клаўдыюша ДужДушэўскага, Янкі Трахімовіча, Адама Станкевіча, Палуты Бадуновай і інш. Ёсць таксама ў гэтым зборы фатаграфіі настаўніц беларускіх школ у Бельску і Беластоку Вольгі Гофман і Вольгі Скаўронскай (1918 год) і самой Веры з вучнямі (1917-1918 гады), групавыя здымкі ўдзельнікаў настаўніцкіх курсаў у Вільні, Пражскай канферэнцыі 1921 года, настаўніцкай канферэнцыі беларускіх школ у Беластоку (1943/1944 год), беларускіх пісьменнікаў 1920 года і інш.

Разам з гэтым захоўваецца перапіска В. Маслоўскай з Ю. Туронкам: 26 лістоў і паштовак ад яе за 1967-1980 гады і сем лістоў ад яго за 1977-1978 гады. 


\section{Дакументы Надзеі Артымовіч}

Яшчэ адзін адмысловы комплекс дакументаў у фондзе Ю. Туронка звязаны $з$ пісьменніцай Надзеяй Артымовіч. Разам з ім таксама быў перададзены каментарый ад гісторыка, які ніжэй публікуецца.

\section{Дакумент № 10}

Інфармацыя для Архіва ЛіМ, Мінск

3 Надзеяй Артымовіч пазнаёміўся восенню 1976 г. Прыйшла да мяне у пошуках «Нівы», хацела перапісаць усе свае вершы, якія да гэтага часу былі надрукаваныя ў гэтым штотыднёвіку. Я ёй запрапанаваў, што сам зраблю тыя выпісы. Перапісваючы, зацікавіўся яе паэзіяй, захацеў яе падтрымаць. Паколькі Надзея была хаатычная, разгубленая, прасіў яе даваць мне прынамсі копію кожнага новага верша. Яна рабіла тое ахвотна, была ўпэўнена, што ў мяне яе вершы не прападуць, што раней нярэдка бывала. Так пачалося супрацоўніцтва, у якім я займаўся яе паэтычнай бухгалтэрыяй: аналізаваў, сістэматызаваў, высылаў у «Ніву» і беластоцкія «Беларускія календары», заахвочваў яе высылаць нешта ў «Маладосць», пісаў нешта пра яе творчасць у «Ніве», арганізаваў аўтарскія вечары.

У сакавіку 1977 г. зрабіў машынапіснае выданне «Розумаў» тыражом... 5 паасобнікаў. Гэта зрабіла на яе адпаведнае ўражанне. Пісала штораз больш. Бадай на кожным вершы была дата напісання, аднак прасіла не друкаваць гэтых дат. Усё знаходзіцца ў архіўных папках.

Вясной 1979 г. Надзея выехала 3 Варшавы ў Бельск у сувязі 3 хваробай маці. 3 гэтага часу пачалася карэспандэнцыя, супрацоўніцтва не спынялася. Летам 1981 г. з'явіўся зборнічак «Роздумаў», а яшчэ ў 1979 г. пераклад вершаў на польскую мову. Вершы, якія былі у мяне, паступова публікаваліся і бадай усё было надрукавана.

Са снежня 1981 г. нашае супрацоўніцтва абарвалася, па сутнасці таксама і карэспандэнцыя. Здаецца, што за мінулае 10-годдзе напісала ўсяго некалькі новых вершаў. Не выключаю, што перашкаджалі асабістыя справы. У 1990 г. выйшаў трэці зборнічак Надзеі Артымовіч - «Сезон у белых пейзажах», у якім надрукаваныя вершы, напісаныя да 1981 г.

Далучаю ўсе тры зборнічкі з аўтарскімі аўтографамі.

Юры Туронак. 
Дзякуючы Ю. Туронку у БДАМЛіМ захоўваюцца лісты і паштоўкі Н. Артымовіч за 1979-1985 гады (42 дакументы), спісы вершаў паэтэсы, складзеныя гісторыкам, выразкі публікацый яе вершаў і тэкстаў пра яе, машынапісы і аўтографы вершаў, якія дасылаліся ў беластоцкую газету «Ніва» і іншыя выданні, а таксама фатаграфіi Н. Артымовіч.

\section{Дакументы да біяграфіі Юрыя Туронка}

Важную частку фонду Ю. Туронка ў БДАМЛіМ складаюць дакументы, звязаныя $з$ яго біяграфіяй. Тут сабраны як разнастайныя пасведчанні аб адукацыі - спачатку хіміка, а потым гісторыка, якую ён атрымліваў у Вільні, Беластоку, Шчэціне, Варшаве. Значны комплекс дакументаў датычыць працы Ю. Туронка ва ўстанове Centrala Importowo-Eksportowa Chemikaliów i Aparatury Chemicznej (Ciech) і на пасадзе рэдактара газеты „Rynki Zagraniczne”. Важныя таксама матэрыялы з навуковай і грамадскай дзейнасці Ю. Туронка як сябра Беларускага грамадска-культурнага таварыства, Міжнароднай асацыяцыі беларусістаў і інш. Цікавасць уяўляюць дакументы, звязаныя з абаронай доктарскай дысертацыі і публікацыяй працы «Беларусь пад нямецкай акупацыяй», матэрыялы пра ўдзел Ю. Туронка ў міжнародных канферэнцыях і іншых мерапрыемствах, як у часе знаходжання на пасадзе рэдактара газеты „Rynki Zagraniczne”, гэтак і ў сувязі з беларусазнаўчай навуковай дзейнасцю. Дастаткова поўна прадстаўлены і дакументы аб дзяржаўных узнагародах Ю. Туронка. Увагу звяртае таксама той факт, што гісторык даволі даўно стаў клапаціцца пра перадачу назбіраных ім кніжных і дакументальных каштоўнасцей. Таму ў фондзе ёсць дакументы аб перадачы гісторыкам Нацыянальнай бібліятэцы ў Варшаве, Нацыянальнай бібліятэцы Беларусі і інш. у дар беларускіх кніг з асабістага збору.

Своеасаблівым дадаткам да біяграфічных дакументаў выступаюць матэрыялы пра Ю. Туронка. Гэта вялікая колькасць рэцэнзій і водгукаў на розныя кнігі гісторыка, а таксама публікацыі Аляк- 
сея Каўкі, Лены Глагоўскай, Язэпа Янушкевіча і інш., прысвечаных фондаўтваральніку. Асаблівую цікавасць выклікае копія спецыяльнага данясення агента Камітэта дзяржаўнай бяспекі БССР «Бурана» пра кантакты з Ю. Туронкам у канцы 1950-х гадоў і каментарыі гісторыка 3 высвятленнем рэальнай асобы згаданага агента, якім аказаўся пісьменнік Алесь Бажко.

\section{Дакументы пра навуковую дзейнасць Ю. Туронка}

Яшчэ ў пачатку 1990-х гадоў у БДАМЛіМ трапілі аўтографы і машынапісы прац Ю. Туронка «Беларусь пад нямецкай акупацыяй», «Памяці Браніслава Туронка», «Да гісторыі друйскага марыянскага манастыра ў 1923-1938 гадах», машынапіс даследавання па сямейнай гісторыі „Reszecie. Zarys genealogii rodziny”, прысвечанай продкам па мацярынскай лініі Рэшацям і зробленай пераважна для сямейнага карыстання ў 2000 годзе, матэрыялы да артыкулаў і варыянты тэкстаў «Дзядзька Антон», «Непакорная Вера» і інш. Ёсць таксама некалькі артыкулаў Ю. Туронка ў газеце „Rynki Zagraniczne” і шэраг інтэрв’ю з гісторыкам, звязаных з яго навукова-даследчай дзейнасцю.

Фонд Ю. Туронка ўтрымлівае таксама вельмі разнастайныя па характары дакументы, сабраныя ім у працэсе падрыхтоўкі сваіх публікацый. Яны адлюстроўваюць шырокае кола інтарэсаў гісторыка. Тут ёсць матэрыялы, звязаныя з выданнем кнігі даследчыцы Ціны Клыкоўскай пра Саюз беларускай моладзі, гісторыяй якога займаўся і Ю. Туронак. Праца над падрыхтоўкай выдання кнігі стала штуршком як для перапіскі, напрыклад, з колішнім сябрам СБМ Міколам Латушкіным, так i, магчыма, для падрыхтоўкі ўласнай працы Ю. Туронка «Людзі СБМ».

У фондзе таксама можна знайсці дакументы да біяграфій Аляксандра Каўша, Юркі Геніюша, Аляксея Грыцука, Міколы Грэбня, Лявона Луцкевіча, Уладзіміра Тарасевіча, Віктара Ярмалковіча і інш., асабліва тых, з кім гісторык перапісваўся. Тут жа звярта- 
юць на сябе ўвагу машынапісы прац В. Ярмалковіча пра Беларускі студэнцкі саюз у Вільні і Беларускую хрысціянскую дэмакратыю, аўтабіяграфічныя тэксты Марыяна Пецюкевіча, артыкулы Пятра Ластаўкі і інш. пра беларускае жыццё ў даваеннай Варшаве, дакументы пра дзейнасць беларусаў на Беласточчыне і шмат іншых публікацый і выпісак, зробленых Ю. Туронкам па розных тэмах.

Асаблівай увагі патрабуе невядомае раней падпольнае выданне «Новая наша ніва» (1979 год), камплект якога некалі перадаў Ю. Туронку польскі даследчык Мікалай Іваноў. Магчыма, выпускі гэтага выдання, што захоўваюцца цяпер у БДАМЛіМ, існуюць цяпер у адзіным экзэмпляры.

\section{Перапіска Ю. Туронка}

Сярод перададзенага Ю. Туронкам у БДАМЛіМ найбольшы аб’ём мае перапіска. Усю карэспандэнцыю гісторыка можна падзяліць на некалькі груп.

Так, Ю. Туронак часта пакідаў сабе аўтарызаваныя копіі лістоў да іншых асоб, у выніку, асобную групу складаюць уласныя лісты Ю. Туронка. Сярод яго адрасатаў можна знайсці даследчыкаў, грамадскіх дзеячаў з розных краін: Сцяпана Александровіча, Міколу Грэбня, Аляксея Каўку, Святаслава Каўша, Міколу Латушкіна, Лявона Луцкевіча, Аляксандра Надсана, Міколу Панькова, Марыяна Пецюкевіча і дзясяткаў іншых. Арыгіналы некаторых уласных лістоў, напрыклад, да Юзафа Александровіча (Язэпа Найдзюка) або Марыяна Пецюкевіча Ю. Туронак атрымаў пасля смерці адрасатаў.

Яшчэ лепш прадстаўлены лісты, дасланыя Ю. Туронку. Паводле аб'ёму перапіскі можна вылучыць асноўных карэспандэнтаў гісторыка: Міколу Грэбня (ЗША), Аляксея Каўку (Расія), Святаслава Каўша (ЗША), Аляксандра Надсана (Вялікабрытанія), Марыяна Пецюкевіча (Польшча), Здзіслава Сямашку (Польшча), Міхаліну Татарыновіч (Польшча), Віктара Ярмалковіча (Польшча). Пера- 
піска Ю. Туронка каштоўная тым, што змяшчае многа факталагічнай інфармацыі па гісторыі беларускага руху міжваеннага і ваеннага часу, матэрыялы да біяграфій тых або іншых яго ўдзельнікаў. Гэтыя звесткі даследчык збіраў для сваіх прац, але, відавочна, скарыстаў далёка не цалкам. Шмат якія лісты суправаджаюцца фатаграфіямі або артыкуламі, іншымі матэрыяламі. Сярод карэспандэнтаў Ю. Туронка гісторыкі, грамадскія дзеячы, сябры з Беласточчыны і іншых рэгіёнаў Польшчы, з Беларусі, калегі-даследчыкі з Германіі, Літвы, Швейцарыі, а таксама значная колькасць дзеячаў беларускай пасляваеннай эміграцыі. Шырокая геаграфія прадвызначыла і моўную разнастайнасць дакументаў: тут прадстаўлены беларуская, польская, руская, англійская, нямецкая, літоўская мовы.

Асобную невялікую групу складае перапіска Ю. Туронка адносна біяграфіі яго бацькі Браніслава. Даследчык актыўна збіраў звесткі з сямейнай гісторыі наогул і пра жыццё і дзейнасць Б. Туронка, якому была прысвечана адна $з$ яго кніг. Гісторык распрацаваў адмысловы апытальнік для сваякоў, прыклады адказаў на які можна знайсці ў згаданых пісьмах.

У яшчэ адну невялікую групу можна вылучыць карэспандэнцыю Ю. Туронка ў справе спадчыны Марыяна Пецюкевіча. Пасля смерці гэтага дзеяча, з якім гісторыка звязвалі доўгія прыяцельскія адносіны, Ю. Туронак клапаціўся пра належнае забеспячэнне захаванасці яго архіва і бібліятэкі ў Акруговым музеі ў Беластоку (цяпер Падляшскі музей у Беластоку), у аддзеле рэдкіх кніг і рукапісаў Цэнтральнай навуковай бібліятэкі імя Якуба Коласа АН БССР (цяпер Нацыянальная акадэмія навук Беларусі).

\section{Выяўленчыя матэрыялы ў фондзе Ю. Туронка}

Багатая на каштоўныя дакументы выяўленчая частка фонда гісторыка. Акрамя прыгаданых вышэй здымкаў з архіваў В. Маслоўскай і Н. Артымовіч, іншыя фатаграфіі можна падзяліць на некалькі груп. Першую складаюць здымкі самога Ю. Туронка, як 
індывідуальныя, гэтак і ў групах з бацькамі, жонкай, дзецьмі, а таксама з калегамі і сябрамі з Беларусі, Польшчы, Францыі і інш.

Да другой групы можна аднесці фатаграфіі па гісторы беларускага нацыянальнага руху, сабраныя Ю. Туронкам. Тут аб'яднаны здымкі са збораў Аўгена Аніські, Міколы Латушкіна і інш., што датычаць як саміх згаданых асоб, гэтак і гістарычных падзей, у якіх яны ўдзельнічалі. Вялікая група здымкаў паходзіць 3 архіваў М. Пецюкевіча. Гэта арыгінальныя фатаграфіi вучняў Радашковіцкай і Віленскай беларускіх гімназій, удзельнікаў Беларускага студэнцкага саюза ў Вільні, урада Таварыства прыяцеляў беларусаведы і групы беларускіх гуманітарыяў віленскага Універсітэта Стэфана Баторыя і інш. Асобна варта адзначыць вялікую колькасць здымкаў, звязаных з адкрыццём помніка на магіле Алеся Гаруна на Ракавіцкіх могілках у Кракаве 24 верасня 1987 года.

Арыгінальныя фатаграфіi са збору М. Пецюкевіча, дапоўненыя вынікамі ўласных пошукаў Ю. Туронка, склалі асобную тэматычную групу «Выявы беларускіх рэлігійных дзеячаў і падзей, сабраныя Юрыем Туронкам». Тут можна ўбачыць арыгіналы і копіі індывідуальных здымкаў ксяндзоў Станіслава Глякоўскага, Яна Семашкевіча (Янкі Быліны), Адама Станкевіча, Віктара Шутовіча і інш., а таксама праваслаўных і каталіцкіх дзеячаў беларускай пасляваеннай эміграцыі. Каштоўнасць уяўляюць арыгінальныя здымкі груп беларускіх рэлігійных дзеячаў, фатаграфіі ўдзельнікаў хору касцёла Святога Мікалая ў Вільні ў суправаджэнні Антона Грыневіча, Адама Станкевіча, Альбіна Стаповіча і інш. Важна адзначыць, што здымкі максімальна анатаваны Ю. Туронкам, што асабліва важна і для архівістаў, і для даследчыкаў.

\section{Дакументы Браніслава Туронка}

Асобную частку фонда Ю. Туронка складаюць сабраныя ім дакументы 3 дзейнасці яго бацькі Браніслава. Сярод іх арыгіналы і копіі біяграфічных дакументаў Б. Туронка і яго жонкі Марыі, рэдкія дру- 
каваныя выданні, як брашура Б. Туронка „Hygijena uzhadawańnia dziciaci”, часопіс «Мой шлях» (1922 год), які ён рэдагаваў. Захаваўся і аўтограф аднаго пісьма Б. Туронка. Таксама ў гэтай частцы фонда сабраны публікацыі пра Б. Туронка, яго фатаграфіі ў групах з сям’ёй, сябрамі і калегамі і схема сядзібы Туронкаў у Дукштах.

\section{Друкаваныя выданні і музейныя прадметы}

Як відаць са змешчаных вышэй лістоў Ю. Туронка, разам з дакументамі ён перадаваў у архіў-музей і разнастайныя друкаваныя выданні, пераважна з міжваеннай Заходняй Беларусі або пасляваеннай беларускай эміграцыі. Самыя раннія з перададзеных: «Богогласник. Сборник церковных песнопений и духовных песен» (Санкт-Пецярбург, 1912), «Колас беларускай нівы» (Гродна, 1913), «Міністэрства беларускіх спраў за 10 месяцаў істнаваньня» М. Засецкага (Каўнас, 1919). Былі перададзены ў архіў-музей розныя віленскія выданні 1930-х гадоў і амаль усе нумары беларускага літаратурна-навуковага часопіса «Калосьсе», які выдаваўся ў Вільні ў 1935-1939 гадах (экзэмпляры паходзяць з бібліятэкі Пётры Ластаўкі).

Дзякуючы Ю. Туронку ў БДАМЛіМ ёсць выданні большасці эміграцыйных паэтаў і пісьменнікаў: Антона Адамовіча, Льва Гарошкі, Міхася Кавыля, Рыгора Крушыны, Яна Пятроўскага, Алеся Салаўя, Масея Сяднёва, Уладзіміра Сядуры-Глыбіннага, Янкі Шакуна, Янкі Юхнаўца і інш. Таксама ў спісе перададзенага гісторыкам - дзясяткі назваў эміграцыйных перыядычных выданняў, сярод якіх асобныя нумары і нават цэлыя камплекты газет «Беларус», «Беларускі час» (1975-1987), часопісаў «Сакавік» (1947-1948), «Шыпшына» (1947-1950), «Веда» (1951-1954), «Летапіс беларускай эміграцыі» (1978-1991), «Конадні» (1954-1963), «Баявая ўскалось» (1962-1981), «Весткі Інстытуту беларусаведы» (19831984), «Зважай» (1989-1991) і інш. Асабліва варта звярнуць увагу на поўны камплект рэдкага выдання беларусаў Мельбурна «Праваслаўным шляхам» (1964-1970). 
Ад Ю. Туронка архіў-музей атрымаў таксама два паясы, сатканыя Нінай Абрамчык, і дзве пласцінкі з запісамі беларускіх песень у выкананні Барбары Вержбаловіч і Вячаслава Селях-Качанскага.

Прадстаўлены тут агляд фонда Ю. Туронка ў БДАМЛМ мае агульны характар. Больш дакладнае яго апісанне будзе дадзена ў вопісе, калі будзе зроблена навукова-тэхнічная апрацоўка дакументаў. Варта дадаць, што фонд гісторыка дагэтуль мае перспектыву папаўнення.

\section{Jerzy Turonek's documents in Belarusian State Archives-Museum of Literature and Arts}

The text is about historian Jerzy Turonek's archival fond in Belarusian State ArchivesMuseum of Literature and Art in Minsk. There are a lot of biographical documents, manuscripts and typescripts of Jerzy Turonek works, photos and correspondence with tens people in different countries. The great part of this archival fond are documents collected by historian to his works from personal collections of Marian Pieciukiewicz, Viera Muraška and others. First parts of these documents were moved in Minsk in early 1990s and last ones are transferring until nowadays. Also thanks to Jerzy Turonek a lot of rare books and periodicals were kept by BSAMLA.

Key wo rds: Jerzy Turonek, archival fond, documents, correspondence, collection 